\title{
Women's entrepreneurship and culture: gender role expectations and identities, societal culture, and the entrepreneurial environment
}

\author{
Amanda Bullough (D) - Ulrike Guelich $(\mathbb{D} \cdot$ \\ Tatiana S. Manolova $\cdot$ Leon Schjoedt $(\mathbb{C}$
}

Accepted: 30 September 2020 / Published online: 9 January 2021

(C) Springer Science+Business Media, LLC, part of Springer Nature 2021

\begin{abstract}
Women's entrepreneurship is increasingly important for creating new jobs and contributing to the social and economic growth of their societies, yet the interplay and nuances of women's entrepreneurship and culture are currently understudied. In this special issue, we present eight empirical papers that delve into different aspects of the dynamic interaction between gender and culture in shaping women's entrepreneurship. We provide framework for women's entrepreneurship and culture research to organize the empirical research herein into three interconnected themes: gender role expectations and identities, societal cultural dimensions, and the entrepreneurial environment. This collection is an
\end{abstract}

\footnotetext{
A. Bullough $(\square)$

Department of Business Administration (LEH 217), Alfred Lerner College of Business \& Economics, University of Delaware,

Newark, DE 19716, USA

e-mail: bullough@udel.edu

U. Guelich

GERA (Global Entrepreneurship Research Association), School of Entrepreneurship and Management, Bangkok University, 119 Rama 4 Rd., Klongtoei, Bangkok 10110, Thailand

e-mail: ulrike.g@bu.ac.th

T. S. Manolova

Bentley University, 175 Forest St., Waltham, MA, USA

e-mail: tmanolova@bentley.edu

L. Schjoedt

Arthur M. Blank Center for Entrepreneurship, Babson College,

231 Forest Street, Babson Park, Wellesley, MA 02457, USA

e-mail: leonschjoedt@gmail.com
}

important step in integrating research on women's entrepreneurship and culture and further exploring these dynamic and complex interactions, in different economic and societal systems and across geographies.

Keywords Women · Entrepreneurship · Gender · Culture

JEL classifications $\mathrm{B} 54 \cdot \mathrm{E} 02 \cdot \mathrm{J} 16 \cdot \mathrm{L} 26 \cdot \mathrm{M} 14$

\section{Introduction}

Women entrepreneurs create jobs and contribute to economic growth and social progress worldwide. From the initial idea, throughout the gestation process, and to business operations and venture growth, their entrepreneurial initiatives are embedded in a complex and multilayered cultural environment. Thus, gender and culture dynamically interact, shaping gender role expectations and identities, and the economic and social environment in which women's entrepreneurship is embedded.

According to the Global Entrepreneurship Monitor (GEM), 231 million women launched or operated businesses in the 59 economies around the world that were studied in the latest 2018/2019 report on women's entrepreneurship (Elam et al. 2019). Many organizations and governmental institutions (ILO 2020; UN Women 2020) have long recognized the importance of women in the process of economic development, individual health, and societal advancement (Bullough et al. 2019). 
Although women entrepreneurs are important for creating new jobs and contributing to the social and economic growth of their societies, the interplay and nuances of women's entrepreneurship, growth, and culture are understudied (Brush et al. 2018; Hechavarria et al. 2019).

Prior research has identified social, cultural, infrastructural, educational, occupational, and role-related obstacles and facilitators to women's entrepreneurship (Baughn et al. 2006; Bullough et al. 2017; Jennings and Brush 2013; Welter and Smallbone 2011). Culture is a multi-layer construct comprising an external, global layer penetrating a society's indigenous layers, and ultimately becoming a set of shared values within groups (Leung et al. 2005; Steel and Taras 2010). Understanding cultural systems is critical for advancing leadership research in varying contexts (Kirkman et al. 2006). Cultural indicators relate to specific beliefs, norms, and expectations within a society that affect societal culture (Fu et al. 2004; Leung et al. 2005). This and the entrepreneurial environment within which businesses are founded and operate together affect women's entrepreneurship.

Culture represents multifaceted explanations for differences in women's entrepreneurship across societies and in the success or failure of business activities. Many barriers and constraints that women entrepreneurs experience are gender specific and stem from cultural values, norms, and customs (Anambane and Adom 2018; Baughn et al. 2006; Khandelwal and Sehgal 2018). Gender egalitarianism, gender role expectations, and the entrepreneurial ecosystem are under-researched cultural factors in women's entrepreneurship (Bullough and Sully de Luque 2015; Eagly and Wood 2016; Hechavarría and Ingram 2019; Manolova et al. 2017). Social customs and expectations are strongly embedded in any culture (Berry et al. 2002; de Bruin et al. 2007; Erez and Gati 2004), and attitudes toward entrepreneurship at least partly reflect subjective perceptions that are prone to bias (Kemp et al. 2015; Marlow et al. 2019; Robinson and Stubberud 2011). Traditionally defined gender roles within the home put household and family responsibilities largely on women, while men provide economically for the family by working outside (Milkie and Peltola 1999; Vinnicombe and Singh 2002). These gender role expectations have traditionally limited women's access to income-earning opportunities (Eagly and Karau 2002; Eagly and Mitchell 2004).
Other research presents more positive notions about culture and women's entrepreneurship (Ahl 2006; Bullough 2013), which to some extent counterbalances the important scholarship done on male and female stereotypes and biases (van Emmerik et al. 2008). While work-life imbalance creates barriers for women starting and running businesses, women have found ways to merge their personal and work lives (Ruderman et al. 2002). Women's capabilities are increasingly recognized as complementary to business goals (Newburry et al. 2008) - skills developed particularly well from the very house responsibilities that can so unevenly impact women, such as multitasking, interpersonal skills, and emotional empathy (Ruderman et al. 2002). Other research from Lucas (2003) shows that as more women are seen leading business, the notion becomes institutionalized and less foreign. This phenomenon helps to shift cultures in a way that reduces barriers to women by adding legitimacy, so that the notion of women in leadership becomes increasingly engrained in a culture's social and economic fabric (Newburry et al. 2008).

This special issue of Small Business Economics: An Entrepreneurship Journal sought papers that fit within the overarching theme of women's entrepreneurship and culture. We invited contributors to investigate female entrepreneurship in a variety of cultural and societal settings, with a particular focus on women's entrepreneurship and culture, interactions between and among cultures and societies, cross-cultural similarities and differences, and the impact of culture and the impact on culture. Emphasis was placed on studies that consider the opportunities, strategies, and business models, as well as the challenges faced in today's increasingly digitized and networked world, emphasizing how women start and grow their businesses. Despite the multifaceted complexities encompassed by a topic as broad as women's entrepreneurship and culture, the eight articles in this special issue fall into three dominating themes that we organized into a framework for women's entrepreneurship and culture research: gender role expectations, societal cultural dimensions, and the entrepreneurial environment (see Fig. 1). In this article, we first review the literature in these three overarching streams, with gender role expectations and identities as the dominating theme. We then distill and organize the various types of primary and secondary data gathered for the work done in these eight articles. Next, we introduce each of the articles with brief summaries of the authors' work. We conclude by suggesting some directions for 


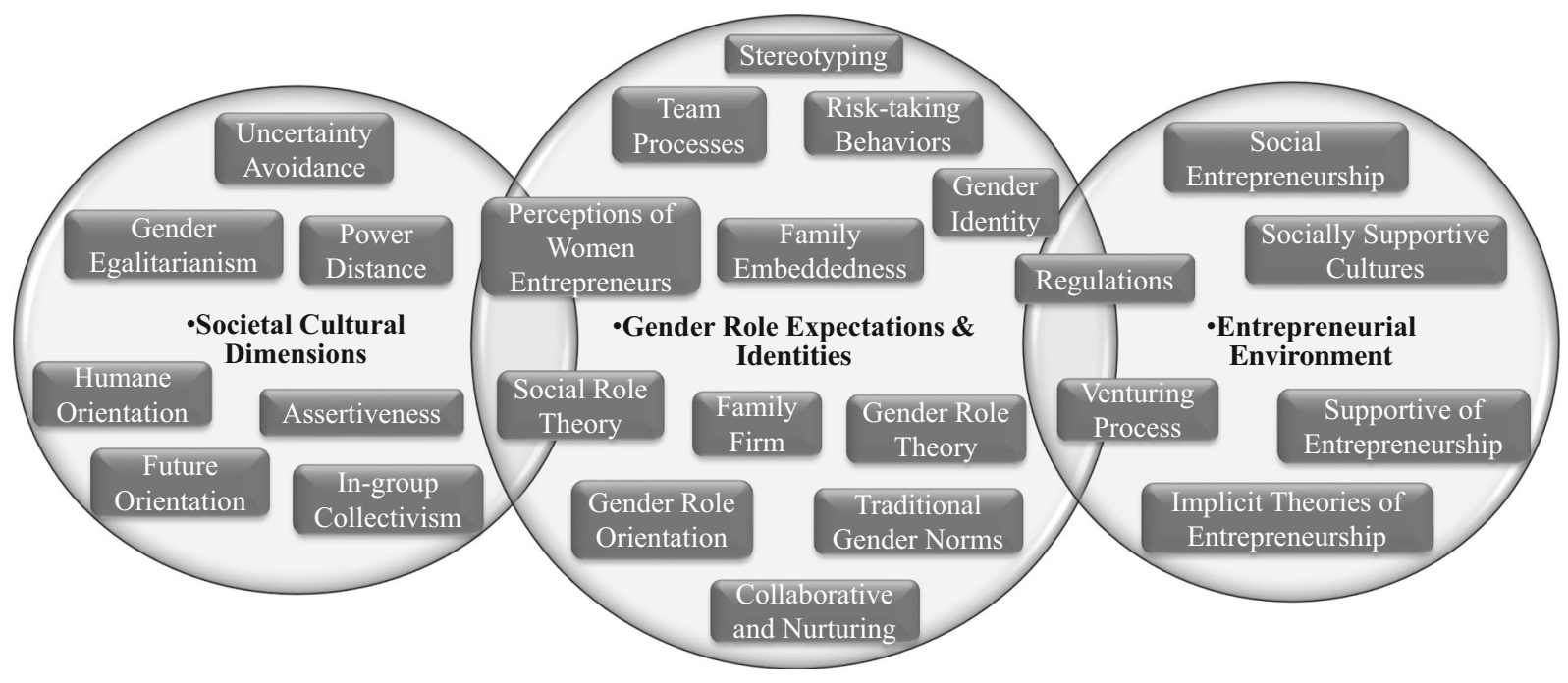

Fig. 1 Framework for women's entrepreneurship and culture research

future research based on the contributions in this special issue.

\section{Gender role expectations and identities}

Research has shown that women often experience bias stemming from expectations of female leadership styles and perceptions of how they lead in practice (Oakley 2000; Prime et al. 2008). Role incongruity theory holds that individuals often find incongruities between their ideas of leadership and their female gender role expectations. This leads to discrimination when women are viewed less favorably than men as potential leaders because expected behaviors for their gender roles are inconsistent with attributions of leadership (Eagly and Karau 2002). Prejudice also happens when prescribed behaviors filled by a leader are viewed less favorably when they are enacted by a woman. The result is that attitudes toward female leaders are less positive, which in turn creates barriers for women becoming leaders and achieving leadership success.

When a specific type of person is repeatedly seen engaging in a particular activity_-like men in leadership positions - individuals tend to associate the abilities and attributes needed for that activity as typical of that specific type of person (Osborn and Vicars 1976). A phenomenon referred to as a "think-leader, think-male" mindset has created obstacles for women owning and running their own business (Jackson et al. 2007; Schein 2001). Sex-role stereotyping happens when men are respected more in business leadership roles because they are believed to possess the masculine traits that are deemed necessary for leadership (Eagly and Mitchell 2004) and are associated with high-growth entrepreneurial ventures, whereas women are associated with low-growth ventures. This particularly occurs and is reinforced in contexts where men are far often than women to be found in leadership positions and in entrepreneurship (Elam et al. 2019; Markussen and Røed 2017; Shahriar 2018). To compensate for some of these challenges, women have developed keen skills for switching between different gender and leadership identities and styles, depending on different contexts (Hytti et al. 2016), which in turn helps them to further develop their relationship building and diplomacy skills.

Research has shown that because women are often associated with being feminine, communal, and compassionate (Ferriman et al. 2009) as opposed to assertive, dominating, and independent, which are characteristics associated more often with men, an incongruity between roles occurs when women's gender rolescaregiving and nurturing - are at odds with perceived leadership characteristics - assertive and competitive (Eagly and Mitchell 2004; Gupta et al. 2019; Powell et al. 2002). These male-female stereotypes, biases, and gender role expectations make entrepreneurial success and growth harder for women than for men, leading to the lacking of funding capital for their businesses (Gupta et al. 2019; Prasad 2009) and smaller professional networks (Kalafatoglu and Mendoza 2017; Mitra and Basit 2019). 
Gender roles for women can be viewed in a more positive light as well. Women more than men have been associated with being nurturing, collaborative, cooperative, affectionate, and concerned for others (Yoder 2001), which are qualities that are particularly important leadership characteristics (Dorfman et al. 2004). Prior research has suggested that women particularly excel at empathy and judging emotions (Kirkland et al. 2013; Macaskill et al. 2002; Mandell and Pherwani 2003), building friendships and community (Ferriman et al. 2009), or managing sensitive relationships (Korac-Kakabadse et al. 1998). Women have also been found to excel at certain global leadership competencies like having a passion for diversity, and intercultural empathy and diplomacy (Javidan et al. 2016). Women would therefore succeed in many of the skills that are needed for building an entrepreneurial team and running a successful business (Eagly and Carli 2003; Ruderman et al. 2002; Vecchio 2002).

Through vicarious learning and social persuasion, aspiring and nascent female entrepreneurs look to other women business owners as direct and indirect role models (Bloemen-Bekx et al. 2019). Role models often come from within the family as daughters learn from and are encouraged by entrepreneurial mothers and fathers, with entrepreneur mothers having a particularly powerful influence on their daughters' aspirations and self-efficacies (Greene et al. 2013; Hoffmann et al. 2015). In this way, women have come to rely on their gender role benefits that stem from family support of their businesses and other female role models. The in-group - defined differently in different cultures, as family only, or a combination of family and close friends - has been found to be particularly important for encouraging a woman's individual goals as an entrepreneur and supporting her business by helping her access networks and resources (Bullough et al. 2017). Because women are influenced by family members and other close relationships, role models also come from peers that other women can relate to, be inspired by, and emulate (Markussen and Røed 2017). Role models have a strong influence on a woman's belief in her entrepreneurial abilities, and therefore influence her intentions to become an entrepreneur (BarNir et al. 2011) and identify as a female business leader (Hytti et al. 2016).

\section{Societal cultural dimensions}

The factors that influence women's entrepreneurship vary depending on circumstance and the dynamic nature of their complex and interconnected lives - in other words, cultural influences. Culture has been defined as "values, beliefs, norms, and behavioral patterns of a national group (Leung et al. 2005, p. 357)," and has been conceptualized as levels that range from the deeply embedded, unconscious, basic assumptions that define the essence of a particular culture, to the external manifestations that are tangible and overt and can be seen and felt by outsiders (E. H. Schein 1992). The middle layers that fall within these two extremes are the beliefs, values, norms, and rules of behavior that dictate the basic principles by which the members of a society operate.

The reciprocal top-down, bottom-up nature of culture makes it a dynamic force, rather than static, where lower levels of culture are nested within higher levels, and change at any level can affect other levels (Erez and Gati 2004; Leung et al. 2005; E. H. Schein 1992). However, because the basic assumptions that guide behavior are shared, culture is powerful because the assumptions are mutually reinforced. Unless they are challenged or debated, it is nearly impossible to change culture without high levels of anxiety among constituents (E. H. Schein 1992), and yet, this is what is needed for women to violate the expected behavioral norms for their gender. Outside influences, like programs, policies, and practices that are designed to encourage women's entrepreneurship (Bullough et al. 2019; Frešer et al. 2019), can offer a scenario where seemingly opposing sets of assumptions can find some common ground. Culture in the ecosystem can be viewed as the "rich complex of meanings, beliefs, practices, symbols, norms, and values prevalent among people in a society (Schwartz 2006, p.138)" and as the "underlying system of values peculiar to a specific group or society (Pinillos and Reyes 2011, p.25)."

Prominent and plentiful research over the last 20 years has used data developed by the GLOBE (The Global Leadership and Organizational Behavior Effectiveness Research Program) Project (House et al. 2004), which is a study of societal-level culture and organizational and leadership effectiveness in 62 countrysocieties based on surveys from 17,000 middle managers in 951 organizations conducted over a 10 -year period. The foundation for the GLOBE measures was Hofstede's original work (Hofstede 1980) and culminated into nine societal-level culture dimensions: future orientation, in-group collectivism, institutional collectivism, power distance, uncertainty avoidance, gender 
egalitarianism, performance orientation, assertiveness, and humane orientation. GLOBE scholars defined culture as "shared motives, values, beliefs, identities, and interpretations or meanings of significant events that result from common experiences of members of collectives that are transmitted across generations (House et al. 2004, p. 15)." This work is particularly relevant for this article because three of the articles in this issue use GLOBE data.

Previous research with GLOBE data on women's entrepreneurship and leadership has been light, but lays a foundation for future work. One study showed that despite high gender egalitarianism - the level of gender equality in society-in some societies, the relative proportion of women to men remains unequal (Chow 2005). Other work found that organizations with more women in management had cultures that were high on humane orientation (fairness, generosity, caregiving, kindness), gender equity, and performance orientation (innovation, improvement, excellence), and low on power distance (authority, power distinction, and status privileges) (Bajdo and Dickson 2001). Another study demonstrated that in lower gender egalitarian cultures, women were rated by their supervisors lower in work-life balance than men, and this mattered for women, not men, in their performance appraisals; this was not found in high gender egalitarian cultures (Lyness and Judiesch 2014). More recent work on collectivism and women's entrepreneurship found that autonomy to pursue individual goals (in-group individualism), combined with support from the in-group (collectivism), creates the best conditions for women to develop businesses, especially in cultures with extreme levels of institutionalism collectivism (highly collectivistic or highly individualistic and the macro-societal level) (Bullough et al. 2017).

\section{The entrepreneurial environment}

A supportive environment for women's entrepreneurship requires unified systems with reciprocal features and a entrepreneurially constructive culture. This includes investments and human and financial capital, opportunities for growth, and a mixture of innovative and progressive institutional and infrastructural provisions (Bullough et al. 2019). Gendered aspects of policies, laws, and cultural expectations are often opaque and subtle, but are deeply rooted in rules, practices, and norms (Brush et al. 2018). Impartial legal and commercial systems that ensure equitable access to financial capital, and promote cultural expectations and practices that support women's businesses, encompass a productive and supportive entrepreneurial ecosystem for women entrepreneurs (Brush et al. 2018; Hechavarría and Ingram 2019).

The attractiveness of entrepreneurship to women can be altered by rules and policies that influence the regulations and costs associated with owning a business (Manolova et al. 2017). Therefore, the professional networks that women assemble and an encouraging ecosystem are critical. Networking helps women overcome gender-based limitations to entrepreneurship by helping them access resources, financial information, and capital, and identify new business opportunities. Women's personal networks are often comprised of private spheres (Bertelsen et al. 2017) that include kinship, friendship, and business or professional ties and influenced by religion, mistrust (Mitra and Basit 2019), and culture and societal expectations (Surangi Hapugoda Achchi Kankanammge Nadee 2018).

Because women have been found to face more gender-based barriers to securing capital for their businesses, such as inherent gender bias capital funding practices, they secure smaller amounts of investment capital and fewer bank loans (Balachandra et al. 2019; Kanze et al. 2017; Wilson 2016). To help women surmount these obstacles, a supportive entrepreneurial environment includes policies that encourage financial institutions to market investment funds and loan products to women directly, and create and assign specific financial products explicitly for women entrepreneurs (Bullough et al. 2019). Attracting more female investors and establishing funds that are led by women and invested in businesses founded and owned by women, should help to create more gender equity in funding practices that are particularly fruitful for women entrepreneurs (Frešer et al. 2019).

\section{Samples and datasets}

As expected for a special issue on women's entrepreneurship and culture, our contributors used primary and secondary data from all over the world and from large and well-respected data sources. Primary data come from large, global databases. Three articles in this issue used data from the Global Leadership and Organizational Behavior Effectiveness (GLOBE) Project (House 
et al. 2004). It is an extension of Hofstede's earlier work on culture's consequences (Hofstede 2006; Tung and Verbeke 2010). Gimenez-Jimenez, Edelman, Dawson, and Calabrò (ms\#126 insert citation in this special issue) use GLOBE's humane orientation and assertiveness measures as an overall measure of socially supportive cultures, developed by Stephan and Uhlaner (2010). Santos and Neumeyer (ms\#137 insert citation in this special issue) used GLOBE's gender egalitarianism measure. Hechavarría and Brieger (ms\#138 insert citation in this special issue) utilize GLOBE's differentiation between espoused societal values (how people believe society "should be") and society's actual practices (as society actually is) for all nine culture dimensions: gender egalitarianism, uncertainty avoidance, power distance, future orientation, humane orientation, performance orientation, assertiveness, institutional collectivism, and in-group collectivism.

Two studies use data from the World Bank's publicly available World Development Indicators (WDI) database (World Bank 2020). Santos and Neumeyer (ms\#137 insert citation in this special issue) utilized total unemployment and the percentage of female selfemployed data. Hechavarría and Brieger (ms\#138 insert citation in this special issue) use WDI data on GDP, unemployment, and population growth.

Two articles use data from the Global Entrepreneurship Monitor (GEM) (Reynolds et al. 2005). The GEM project represents the largest and widely recognized dataset on global entrepreneurial activity (Bergmann et al. 2014). Hechavarría and Brieger (ms\#138 insert citation in this special issue) included data from business owners, ages 18-64, from 2009 and 2015, and classified their status as a nascent entrepreneur, baby business owner, or an established business owner. Santos and Neumeyer (ms\#137 insert citation in this special issue) used the GEM National Experts with questions answered by a sample of a minimum of 36 experts per country in their study.

Three other studies in this issue utilized data from three different secondary sources. One study in this issue by Gimenez-Jimenez, Edelman, Dawson, and Calabrò (ms\#126 insert citation in this special issue) used data from the Global University Entrepreneurial Student Spirit Study (GUESSS) survey (Sieger et al. 2014) to measure risk-taking behavior. The GUESSS project is an ongoing study of the founding intentions and startup activities of university students in 34 countries. Another study by Vershinina, Markman, Rodgers, Han, Kitching,
Hashimzade, and Barrett (ms\#135 insert citation in this special issue) utilized firm-level survey data from 27 European countries collected by the Business Environment and Enterprise Performance Survey (BEEPS), through a partnership between the European Bank for Reconstruction and Development (EBRD) and the World Bank (EBRD 2020). The third study by Feldmann, Lukes, and Uhlaner (ms\#158 insert citation in this special issue) used family business data from the Cultural Pathways of Economic Self-Sufficiency and Entrepreneurship (CUPESSE) project in 11 counties (Tosun 2016).

Four of our eight articles in this issue collected their own primary data. In addition to their use of secondary data sources, Santos and Neumeyer (ms\#137 insert citation in this special issue) also collected their own primary data from 64 entrepreneurial teams in a technology startup accelerator that snaps 20 countries. Martiarena (ms\#104 insert citation in this special issue) created a new, primary dataset with a survey of 710 business owners to create a representative sample in terms of age and gender in 10 countries. Gupta, Batra, and Gupta (ms\#124 insert citation in this special issue) collected primary survey data of working adults and business students in the USA and India. And, finally, Liñán, Jaén, and Martín (ms\#146 insert citation in this special issue) collected their own survey data from 1195 Spanish women to understand the cultural interplay between gender role expectations and entrepreneurially supportive cultures. Theirs is the only single-country study of culture in the issue.

\section{The articles in this issue}

By applying a family embeddedness perspective and a multi-level view of culture, Feldmann, Lukes, and Uhlaner (ms\#158 insert citation in this special issue) analyze gender norms at the family and society levels in their article "Disentangling Succession and Entrepreneurship Gender Gaps: Gender Norms, Culture, and Family." With a sample of 2897 young adults in 11 European countries who have at least one selfemployed parent, their results show a significant relationship between gender identity and career status. Women were found to be more likely than men to be an employee in a family firm than a successor, but no significant differences were found in the likelihood of women being founders. The authors found nuances that explain these relationships further. Women with 
childcare responsibilities who live by traditional gender norms and have a self-employed mother are more likely to be a successor than being either an employee or a founder - $\mathrm{a}$ finding that reverses gender identity main effects. The authors theorize the explanation of these findings by employing an understanding of culture in occupational choice and a family embeddedness perspective (Aldrich and Cliff 2003), which explains that entrepreneurship is inextricably intertwined with family-related roles and caregiving responsibilities. Feldmann, Lukes, and Uhlaner propose that caregiving may lead women to become self-employed, and primarily into succession as opposed to founding, because family businesses can help daughters balance childcare and career.

In the article "How gender stereotypes shape venture growth expectations," Martiarena (ms\#104 insert citation in this special issue) draws on gender role theories to study how masculine stereotyping of entrepreneurs influences expectations of firm's growth on the part of the business owner. She explores the relationships among gender traits that business owners attribute to other entrepreneurs along with their own gender identity, within the industrial context in which the businesses operate. This study of individual-level psychological constructs within an industrial context is based on primary data from a survey of 710 business owners in 10 countries. Martiarena's findings reveal that women entrepreneurs expect a lower growth rate for their businesses when they identify themselves with feminine traits and attribute masculine characteristics to entrepreneurship. However, these stereotypes are only relevant in industries with a low participation from women in entrepreneurship. The author believes the explanation for this finding to stem from the visibility of gender as an issue because of the rarity of women business owners, which in turn triggers stereotype threats.

"Culture and Gender in Entrepreneurial Teams: The Effect on Team Processes and Outcomes" by Santos and Neumeyer (ms\#137 insert citation in this special issue) is a study that examines survey data of 64 entrepreneurial teams from 20 countries in an international technology startup accelerator, and secondary data from Project GLOBE (House et al. 2004), Global Entrepreneurship Monitor (GEM) (Reynolds et al. 2005), and the World Development Indicators (WDI) database (World Bank 2020) to understand the participation of women in entrepreneurial team processes. They specifically study the mediating role of team reflexivity, which involves intentionally reconsidering — reflecting — strategies and processes in order to identify gaps between current and desired circumstances and adapt as needed (Schippers et al. 2008; West 1996). They find that team reflexivity mediates the relationship between the proportion of women in a team and a team's access to resources. Santos and Neumeyer theorize that the explanation for this mediating relationship is women's collaborative and nurturing abilities (Eagly and Karau 2002) to facilitate shared goal clarity and include others' input and minimize power differences. They explain that these behaviors are consistent with women's gender identity and the conditions that make team reflexivity possible. The authors also find this mediation to be strongest inor moderated by-countries with predominately positive cultural attitudes toward women's entrepreneurship. They posit that such positive perceptions about women entrepreneurs (Yousafzai et al. 2015) influence the quality of team processes and therefore increase its access to resources.

In the article "Does entrepreneurship fit her? Women entrepreneurs, gender role orientation and entrepreneurial culture," Liñán, Jaén, and Martín (ms\#146 insert citation in this special issue) examine how gender role orientation and perceived entrepreneurial culture are related to women's progression through the process of venture creation. By employing Bem's Sex Role Inventory (Bem 1981) to collect survey data from 1195 Spanish women, the authors identify that masculine and androgynous gender role orientations are more likely to lead to entrepreneurial activity than women who identify more with femininity. They also find that the positive relationship between masculinity and entrepreneurial activity is strongest in community cultures that are perceived to be supportive of entrepreneurship (Reynolds et al. 2005). The results confirm that women with a masculine or androgynous orientation are more likely to develop entrepreneurial careers.

"Gender, Culture, and Implicit Theories about Entrepreneurs: A Cross-National Investigation," by Gupta, Batra, and Gupta (ms\#124 insert citation in this special issue), provides an examination of implicit theories of entrepreneurship, an important aspect of which is gender, based on survey data of working adults and business students in the USA and India. The authors find that in the USA, masculine (e.g., dominating, competitive) as opposed to feminine characteristics (e.g., nurturing, caring for others) are predominately attributed to entrepreneurs, and these masculine characteristics are 
also consistent with social role expectations for men and inconsistent with expected characteristics of women. This means that American men, not women, are seen as entrepreneurs because this career choice is consistent with men's masculine characteristic. Furthermore, highgrowth and commercial businesses were associated with men in the USA, while low-growth and social businesses were associated with women. In India, on the other hand, both masculine and feminine characteristics - more androgynous - are ascribed to entrepreneurs. Because the characteristics expected of entrepreneurs are consistent with the qualities expected of both women and men in India, this means that both genders are recognized as entrepreneurs. When examining the relationship between gender and growth orientation in India, neither high- nor low-growth ventures were associated with either gender. To interpret these results, Gupta, Batra, and Gupta explain that the social role theory (Eagly and Karau 2002; Eagly and Wood 2016) helps us understand how gender stereotypes for entrepreneurs are different in these two countries. The authors argue that these implicit theories about entrepreneurs are caused by socio-economic and cultural conditions of a society regarding how people perceive and respond to social role expectations.

Gimenez-Jimenez, Edelman, Dawson, and Calabrò (ms\#126 insert citation in this special issue) explore the impact of risk aversion and country-level culture on the venturing process of women's businesses with data from Project GLOBE (House et al. 2004) and the GUESSS project (Sieger et al. 2014) from 1552 nascent student entrepreneurs in 11 countries. They find that women's perceptions of risk-taking behaviors are associated with less progress in the venturing process, but this relationship is weakened in socially supportive cultures - those that are concerned for the welfare of others (humane orientation) and tender and helpful (low on assertiveness) (Ute Stephan and Uhlaner 2010; Ute Stephan et al. 2015). For men, none of these variables is statistically related. We learn from this research that helping women to gain access to resources through programs and incentives in socially supportive environments may moderate new venture startup risks.

In the article "Gendered Regulations and SMEs' Performance in Transition Economies," Vershinina, Markman, Rodgers, Han, Kitching, Hashimzade, and Barrett (ms\#135 insert citation in this special issue) study survey data from firms in 27 European countries collected by the Business Environment and Enterprise
Performance Survey (BEEPS), through a partnership between the European Bank for Reconstruction and Development (EBRD) and the World Bank. They studied the relationship between regulations - such as employee welfare, consumer safety, environmental protection, and equitable competition-and SME performance. They find that women take regulations more seriously and achieve improved SME performance, but when they respond to regulatory enforcers, the performance of their firms declines. Men by comparison experience lower SME performance and pay less attention to the influence of regulations, but when they engage enforcers, the performance of their firms improves. The authors suggest that regulations are not gender neutral and instead perpetuate gender biases.

Hechavarría and Brieger in "Practice Rather Than Preach: Cultural Practices and Female Social Entrepreneurship (ms\#138 insert citation in this special issue)" analyze data from the Global Entrepreneurship Monitor (GEM), the Global Leadership and Organizational Behavior Effectiveness (GLOBE) Project (House et al. 2004), and the World Bank in 33 countries and more than 23,000 entrepreneurs to understand in what way culture is most relevant for social entrepreneurship among female business owners. They find that women are more likely than men to start socially oriented businesses in cultures where power is distributed evenly (low power distance), people are less helpful and supportive of others (low humane orientation), individual goals and accomplishments are celebrated (low in-group collectivism), people plan for the future (high future orientation), and comfort with unpredictability is low (high uncertainty avoidance).

Collectively, the studies in this issue elucidate how gender and culture dynamically interact, how they affect the types of entrepreneurial activity women undertake, and women's effectiveness in pursuing entrepreneurial initiatives. Thus, this body of work demonstrates the value of a more holistic perspective, which incorporates multiple levels of gender-culture interaction across different areas of entrepreneurial action.

\section{Discussion and conclusions}

This special issue was motivated by the important role of women's entrepreneurship for economic, societal, and environmental value creation worldwide. It is widely recognized that women face gender-specific 
opportunities and challenges in their entrepreneurial endeavors. Yet, research on how gender and culture dynamically interact; how culture affects women's entrepreneurship at multiple levels (i.e., individual, team, company, region, and society as a whole); and how women's entrepreneurial activity in turn affects social norms, values, and practices, has so far been fragmented and scattered across multiple theoretical platforms. In this special issue, we collected and organized empirical research into a framework for women's entrepreneurship and culture research with three overlapping themes that include gender role expectations and identities, societal cultural dimensions, and the entrepreneurial environment. We offer suggestions for future research here based on these three themes.

\subsection{Gender role expectations and identities}

- What are gender role expectations and identities from an intersectionality perspective? What are some of the tensions and/or reinforcing loops that exist when we holistically consider multiple entrepreneur identities? How do these affect entrepreneurial opportunities and challenges?

- Given the traditional gender role of women as family caretakers, how do humanitarian disasters and economic crises such as the current COVID-19 pandemic affect gender role expectations and identities?

- How does women's entrepreneurial activity affect perceived gender role expectations at different levels (i.e., community, region, country) and in different spheres (i.e., family, business, social enterprises)?

\subsection{Societal cultural dimensions}

- How does women's entrepreneurial activity affect cultural values and practices? Is there a differential effect on cultural values versus cultural practices? Is there a differential effect based on types of entrepreneurial activity undertaken by women (i.e., commercial versus social entrepreneurship) or high-growth versus low-growth entrepreneurship?

- What are the overlaps and tensions when applying different societal cultural lenses on women's entrepreneurship (i.e., Hofstede, GLOBE, the Schwartz culture model)? What can we claim as cumulative knowledge and what are some of the gaps and paradoxes?
- How would the current "de-globalization" trend affect social values and norms with respect to women's entrepreneurship? Would traditional social cultural values ossify or continue to evolve toward cultural convergence?

\subsection{The entrepreneurial environment}

- What is the relative effect of community, firm-level, and societal cultural values and norms on the trajectory and outcomes of entrepreneurial initiatives?

- What is the effect of digitization on the entrepreneurial environment with respect to gender role expectations and identities?

- Is the digital environment for women's entrepreneurship culturally shaped? If so, through what mechanisms and with what outcomes?

In conclusion, in this special issue of Small Business Economics: An Entrepreneurship Journal, we present conceptually rich and empirically robust investigations into the multiple points of interaction among gender, culture, and entrepreneurship. This collection is an important step in integrating research on women's entrepreneurship and culture and further exploring their dynamic interaction in different economic and social systems and across geographies. There is still significant research to be done in this area. It is our hope that our collection of studies herein will serve as a springboard that inspires further work in this exciting area of research, and that other colleagues will join in this important conversation.

\section{Compliance with ethical standards}

Conflict of interest The authors declare that they have no conflict of interest.

\section{References}

Ahl, H. (2006). Why research on women entrepreneurs needs new directions. Entrepreneurship Theory and Practice, 30(5), 595-622.

Aldrich, H. E., \& Cliff, J. (2003). The pervasive effects of family on entrepreneurship: toward a family embeddedness perspective. Journal of Business Venturing, 18, 573-596. 
Anambane, G., \& Adom, K. (2018). Assessing the role of culture in female entrepreneurship in contemporary Sub-Saharan society: insights from Nabadam district of Ghana. Journal of Developmental Entrepreneurship, 23(3). https://doi. org/10.1142/S1084946718500176.

Bajdo, L. M., \& Dickson, M. W. (2001). Perceptions of organizational culture and women's advancement in organizations: a cross-cultural examination. Sex Roles, 45(5/6), 399.

Balachandra, L., Briggs, T., Eddleston, K., \& Brush, C. (2019). Don't pitch like a girl!: how gender stereotypes influence investor decisions. Entrepreneurship Theory and Practice, 43(1), 116-137.

BarNir, A., Watson, W. E., \& Hutchins, H. M. (2011). Mediation and moderated mediation in the relationship among role models, self-efficacy, entrepreneurial career intention, and gender. Journal of Applied Social Psychology, 41(2), 270297.

Baughn, C. C., Chua, B.-L., \& Neupert, K. E. (2006). The normative context for women's participation in entrepreneruship: a multicountry study. Entrepreneurship Theory \& Practice, 30(5), 687-708.

Bem, S. L. (1981). Gender schema theory: a cognitive account of sex typing. Psychological Review, 88(4), 354-364.

Bergmann, H., Mueller, S., \& Schrettle, T. (2014). The use of global entrepreneurship monitor data in academic research: a critical inventory and future potentials. International Journal of Entrepreneurial Venturing, 6(3), 242-276. https://doi. org/10.1504/IJEV.2014.064691.

Berry, J. W., Poortinga, Y. H., Segall, M. H., \& Dasen, P. R. (2002). Cross-cultural psychology: research and application (2nd ed.). New York: Cambridge University Press.

Bertelsen, R. G., Ashourizadeh, S., Kent Wickstrøm, J., Schøtt, T., \& Cheng, Y. (2017). Networks around entrepreneurs: gendering in China and countries around the Persian Gulf. Gender in Management, 32(4), 268-280. https://doi. org/10.1108/GM-03-2016-0030.

Bloemen-Bekx, M., Voordeckers, W., Remery, C., \& Schippers, J. (2019). Following in parental footsteps? The influence of gender and learning experiences on entrepreneurial intentions. International Small Business Journal, 37(6), 642663. https://doi.org/10.1177/0266242619838936.

Brush, C., Edelman, L. F., Manolova, T., \& Welter, F. (2018). A gendered look at entrepreneurship ecosystems. Small Business Economics, 52(3), 393-408. https://doi. org/10.1007/s11187-018-9992-9.

Bullough, A. (2013). Perceptions of women entrepreneurs in male-dominated leadership cultures: more positive support for women than many thought. Journal of Enterprising Culture, 21(3), 359-374.

Bullough, A., \& Sully de Luque, M. (2015). Women's participation in entrepreneurial and political leadership: the importance of culturally endorsed implicit leadership theories. Leadership, 11(1), 36-56.

Bullough, A., Renko, M., \& Abdelzaher, D. (2017). Women's entrepreneurship: operating within the context of institutional and in-group collectivism. Journal of Management, 43(7), 2037-2064. https://doi.org/10.1177/0149206314561302.

Bullough, A., Hechavarria, D., Brush, C., \& Edelman, L. (Eds.). (2019). High-growth women's entrepreneurship programs, policies and practices. Cheltenham: Edward Elgar Publishing.
Chow, I. H.-S. (2005). Gender differences in perceived leadership effectiveness in Hong Kong. Women in Management Review, 20(3/4), 216-233.

de Bruin, A., Brush, C. G., \& Welter, F. (2007). Advancing a framework for coherent research on women's entrepreneurship. Entrepreneurship Theory and Practice, 31(3), 323339.

Dorfman, P. W., Hanges, P. J., \& Brodbeck, F. C. (2004). Leadership and cultural variation: identification of culturally endorsed leadership profiles. In R. J. House, P. J. Hanges, M. Javidan, P. W. Dorfman, \& V. Gupta (Eds.), Culture, leadership and organizations: the GLOBE study of 62 societies (pp. 669-719). Thousand Oaks: Sage Publications.

Eagly, A. H., \& Carli, L. L. (2003). Finding gender advantage and disadvantage: systematic research integration is the solution. Leadership Quarterly, 14(6), 851.

Eagly, A. H., \& Karau, S. J. (2002). Role congruity theory of prejudice toward female leaders. Psychological Review, 109(3), 573-598.

Eagly, A. H., \& Mitchell, A. (2004). Social role theory of sex differences and similarities: implications for the sociopolitical attitudes of women and men. In M. A. Paludi (Ed.), Praeger guide to the psychology of gender. Westport: Praeger.

Eagly, A. H., \& Wood, W. (2016). Social role theory of sex differences. In The Wiley Blackwell encyclopedia of gender and sexuality studies (pp. 1-3). https://doi.org/10.1002 /9781118663219.wbegss183.

EBRD (2020). World Bank Business Environment and Enterprise Performance Survey (BEEPS). August 7, 2020: https://www. ebrd.com/what-we-do/economic-research-and-data/data. html.

Elam, A. B., Brush, C. G., Greene, P. G., Baumer, B., Dean, M., \& Heavlow, R. (2019) Global Entrepreneurship Monitor 2018/ 2019 women's entrepreneurship report. Babson College, Smith College, and the Global Entrepreneurship Research Association (GERA). July 21, 2020: https://www. gemconsortium.org/report/gem-20182019-womensentrepreneurship-report.

Erez, M., \& Gati, E. (2004). A dynamic, multi-level model of culture: from the micro level of the individual to the macro level of a global culture. Applied Psychology: An International Review, 53(4), 583-598.

Ferriman, K., Lubinski, D., \& Benbow, C. P. (2009). Work preferences, life values, and personal views of top math/ science graduate students and the profoundly gifted: developmental changes and gender differences during emerging adulthood and parenthood. Journal of Personality and Social Psychology, 97(3), 517.

Frešer, B., Širec, K., \& Tominc, P. (2019). Gender gap in perceived financing opportunities for high-growth enterprises. In A. Bullough, D. Hechavarria, C. Brush, \& L. Edelman (Eds.), High-growth Women's Entrepreneurship Programs, Policies and Practices. Cheltenham: Edward Elgar Publishing.

Fu, P. P., Kennedy, J., Tata, J., Yukl, G., Bond, M. H., Peng, T.K., et al. (2004). The impact of societal cultural values and individual social beliefs on the perceived effectiveness of managerial influence strategies: a meso approach. Journal of International Business Studies, 35(4), 284-305. 
Greene, F. J., Han, L., \& Marlow, S. (2013). Like mother, like daughter? Analyzing maternal influences upon women's entrepreneurial propensity. Entrepreneurship Theory and Practice, 37(4), 687-711. https://doi.org/10.1111/j.15406520.2011.00484.x.

Gupta, V. K., Wieland, A. M., \& Turban, D. B. (2019). Gender characterizations in entrepreneurship: a multi-level investigation of sex-role stereotypes about high-growth, commercial, and social entrepreneurs. Journal of Small Business Management, 57(1), 131-153. https://doi.org/10.1111 jjsbm. 12495.

Hechavarría, D. M., \& Ingram, A. E. (2019). Entrepreneurial ecosystem conditions and gendered national-level entrepreneurial activity: a 14-year panel study of GEM. Small Business Economics, 53(2), 431-458. https://doi. org/10.1007/s11187-018-9994-7.

Hechavarria, D., Bullough, A., Brush, C., \& Edelman, L. (2019). High growth women's entrepreneurship: fueling social and economic development. Journal of Small Business Management, 57(1), 5-13.

Hoffmann, A., Junge, M., \& Malchow-Møller, N. (2015). Running in the family: parental role models in entrepreneurship. Small Business Economics, 44(1), 79-104. https://doi. org/10.1007/s11187-014-9586-0.

Hofstede, G. (1980). Culture's consequences: international differences in work-related values. Beverly Hills: Sage.

Hofstede, G. (2006). What did GLOBE really measure? Researchers' minds versus respondents' minds. Journal of International Business Studies, 37, 882-896.

House, R. J., Hanges, P. J., Javidan, M., Dorfman, P. W., \& Gupta, V. (Eds.). (2004). Culture, leadership and organizations: the GLOBE study of 62 societies. Thousand Oaks: Sage Publications.

Hytti, U., Alsos, G. A., Heinonen, J., \& Ljunggren, E. (2016). Navigating the family business: a gendered analysis of identity construction of daughters. International Small Business Journal, 35(6), 665-686. https://doi.org/10.1177 /0266242616675924.

ILO. (2020). International labor organization: gender equality, from https://www.ilo.org/global/topics/equality-anddiscrimination/gender-equality/lang $\% 2 \mathrm{D} \% 2 \mathrm{Den} / \mathrm{index} . \mathrm{htm}$. Accessed 10 July 2020.

Jackson, D., Engstrom, E., \& Emmers-Sommer, T. (2007). Think leader, think male and female: sex vs. seating arrangement as leadership cues. Sex Roles, 57, 713-723.

Javidan, M., Bullough, A., \& Dibble, R. (2016). Mind the gap: gender differences in global leadership self-efficacies. Academy of Management Perspectives, 30(1), 59-73.

Jennings, J. E., \& Brush, C. G. (2013). Research on women entrepreneurs: Challenges to (and from) the broader entrepreneurship literature? The Academy of Management Annals, $71(1), 663-715$.

Kalafatoglu, T., \& Mendoza, X. (2017). The impact of gender and culture on networking and venture creation. Cross Cultural \& Strategic Management, 24(2), 332-349. https://doi. org/10.1108/CCSM-04-2016-0090.

Kanze, D., Huang, L., Conley, M. A., \& Higgins, E. T. (2017). Male and female entrepreneurs get asked different questions by VCs - and it affects how much funding they get. Harvard Business Review (June).
Kemp, L. J., Madsen, S. R., \& Davis, J. (2015). Women in business leadership: a comparative study of countries in the Gulf Arab states. International Journal of Cross Cultural Management : CCM, 15(2), 215-233.

Khandelwal, P., \& Sehgal, A. (2018). Exploring work-family interface for Indian women entrepreneurs. Gender in Management, 33(3), 203-216. https://doi.org/10.1108/GM04-2016-0075.

Kirkland, R. A., Peterson, E., Baker, C. A., Miller, S., \& Pulos, S. (2013). Meta-analysis reveals adult female superiority in "Reading the Mind in the Eyes Test". North American Journal of Psychology, 15(1), 121-146.

Kirkman, B. L., Lowe, K. B., \& Gibson, C. B. (2006). A quarter century of culture's consequences: a review of empirical research incorporating Hofstede's cultural values framework. Journal of International Business Studies, 37(3), 285-320.

Korac-Kakabadse, A., Korac-Kakabadse, N., \& Myers, A. (1998). Demographics and leadership philosophy: exploring gender differences. The Journal of Management Development, 17(5), 351-388.

Leung, K., Bhagat, R. S., Buchan, N. R., Erez, M., \& Gibson, C. B. (2005). Culture and international business: recent advances and their implications for future research. Journal of International Business Studies, 36(4), 357-378.

Lucas, J. W. (2003). Status processes and the institutionalization of women as leaders. American Sociological Review, 68(3), 464-480.

Lyness, K. S., \& Judiesch, M. K. (2014). Gender egalitarianism and work-life balance for managers: multisource perspectives in 36 countries. Applied Psychology, 63(1), 96-129.

Macaskill, A., Maltby, J., \& Day, L. (2002). Forgiveness of self and others and emotional empathy. The Journal of Social Psychology, 142(5), 663-665.

Mandell, B., \& Pherwani, S. (2003). Relationship between emotional intelligence and transformational leadership style: a gender comparison. Journal of Business and Psychology, 17(3), 387-387.

Manolova, T. S., Brush, C. G., Edelman, L. F., Robb, A., \& Welter, F. (2017). Entrepreneurial ecosystems and growth of women's entrepreneurship. Cheltenham: Edward Elgar Publishing.

Markussen, S., \& Røed, K. (2017). The gender gap in entrepreneurship: the role of peer effects. Journal of Economic Behavior \& Organization, 134, 356-373. https://doi. org/10.1016/j.jebo.2016.12.013.

Marlow, S., Hicks, S., \& Treanor, L. (2019). Gendering entrepreneurial behaviour. In M. M. \& C. J. (Eds.), Entrepreneurial Behaviour: Palgrave Macmillan, Cham.

Milkie, M. A., \& Peltola, P. (1999). Playing all the roles: gender and the work-family balancing act. Journal of Marriage and the Family, 61, 476-490.

Mitra, J., \& Basit, A. (2019). Personal networks and growth aspirations: a case study of second-generation, Muslim, female entrepreneurs. Small Business Economics, 1-23. https://doi.org/10.1007/s11187-019-00211-3.

Newburry, W., Belkin, L. Y., \& Ansari, P. (2008). Perceived career opportunities from globalization: globalization capabilities and attitudes towards women in Iran and the US. Journal of International Business Studies, 39(5), 814-832. 
Oakley, J. G. (2000). Gender-based barriers to senior management positions: understanding the scarcity of female CEOs. Journal of Business Ethics, 27(4), 321-324.

Osborn, R. N., \& Vicars, W. M. (1976). Sex stereotypes: an artifact in leader behavior and subordinate satisfaction analysis? Academy of Management Journal, 19, 439-449.

Pinillos, M.-J., \& Reyes, L. (2011). Relationship between individualist-collectivist culture and entrepreneurial activity: evidence from Global Entrepreneurship Monitor data. Small Business Economics, 37, 23-37.

Powell, G. N., Butterfield, D. A., \& Parent, J. D. (2002). Gender and managerial stereotypes: have the times changed? Journal of Management, 28(2), 177-193.

Prasad, R. M. (2009). Loan hurdles: do banks discriminate against women entrepreneurs? The Academy of Management Perspectives, 23(4), 91.

Prime, J., Jonsen, K., Carter, N., \& Maznevski, M. L. (2008). Managers' perceptions of women and men leaders: a cross cultural comparison. International Journal of Cross Cultural Management, 8(2), 171-210.

Reynolds, P. D., Bosma, N., Autio, E., Hunt, S., De Bono, N., Servais, I., et al. (2005). Global entrepreneurship monitor: data collection design and implementation: 1998-2003. Small Business Economics, 24, 205-231.

Robinson, S., \& Stubberud, H. A. (2011). Gender differences in entrepreneurs' perceived problems, profits, and plans. International Journal of Entrepreneurship, 15, 25-44.

Ruderman, M. N., Ohlott, P. J., Panzer, K., \& King, S. N. (2002). Benefits for multiple roles for managerial women. Academy of Management Journal, 45(2), 369-386.

Schein, E. H. (1992). Organizational culture and leadership. San Francisco: Jossey-Bass.

Schein, V. E. (2001). A global look at psychological barriers to women's progress in management. Journal of Social Issues, 57(4), 675-688.

Schippers, M. C., Den Hartog, D. N. D., Koopman, P. L., \& van Knippenberg, D. (2008). The role of transformational leadership in enhancing team reflexivity. Human Relations, 61(11), 1593-1616. https://doi.org/10.1177/0018726708096639.

Schwartz, S. H. (2006). A theory of cultural value orientations: explication and applications. Comparative Sociology, 5(2), 137-182.

Shahriar, A. Z. M. (2018). Gender differences in entrepreneurial propensity: evidence from matrilineal and patriarchal societies. Journal of Business Venturing, 33(6), 762-779. https://doi.org/10.1016/j.jbusvent.2018.04.005.

Sieger, P., Fueglistaller, U., \& Zellweger, T. (2014). Student entrepreneurship across the globe: a look at intensions and activities, International Report GUESSS 2013/2014.July 10, 2020 : h t t p : / / w w w. g u e s s s u r v e y. org/publications/publications/international-reports.html.

Steel, P., \& Taras, V. (2010). Culture as a consequence: a multilevel multivariate meta-analysis of the effects of individual and country characteristics on work-related cultural values. Journal of International Management, 16(3), 211-233.

Stephan, U., \& Uhlaner, L. M. (2010). Performance-based vs socially supportive culture: a cross-national study of descriptive norms and entrepreneurship. Journal of International
Business Studies, 41(8), 1347-1364. https://doi.org/10.1057 /jibs.2010.14.

Stephan, U., Uhlaner, L. M., \& Stride, C. (2015). Institutions and social entrepreneurship: the role of institutional voids, institutional support, and institutional configurations. Journal of International Business Studies, 46(3), 308-331. https://doi. org/10.1057/jibs.2014.38.

Surangi Hapugoda Achchi Kankanammge Nadee, S. (2018). What influences the networking behaviours of female entrepreneurs? International Journal of Gender and Entrepreneurship, 10(2), 116-133. https://doi.org/10.1108 /IJGE-08-2017-0049.

Tosun, J. (2016). Cultural pathways to economic self-sufficiency and entrepreneurship: family values and youth unemployment in Europe (CUPESSE). August 7, 2020: https://cordis. europa.eu/project/id/613257.

Tung, R. L., \& Verbeke, A. (2010). Beyond Hofstede and GLOBE: improving the quality of cross-cultural research. Journal of International Business Studies, 41, 1259-1274.

UN Women. (2020). United Nations entity for gender equality and the empowerment of women Retrieved August 10, 2020, from https:/www.un.org/womenwatch/daw/daw/index.html

van Emmerik, H., Euwema, M. C., \& Wendt, H. (2008). Leadership behaviors around the world: the relative importance of gender versus cultural background. International Journal of Cross Cultural Management, 8(3), 297-315.

Vecchio, R. P. (2002). Leadership and gender advantage. The Leadership Quarterly, 13(6), 643-671.

Vinnicombe, S., \& Singh, V. (2002). Sex role stereotyping and requisites of successful top managers. Women in Management Review, 17(3/4), 120-130.

Welter, F., \& Smallbone, D. (2011). The embeddedness of women's entrepreneurship in a transition context. In E. G. Candida Brush, Colette Henry, Anne de Bruin (Eds.), Women entrepreneurs and the global environment for growth: A research perspective (pp. 96-117). Cheltenham: Edward Elgar.

West, M. A. (1996). Reflexivity and work group effectiveness: a conceptual integration. In M. A. West (Ed.), Handbook of work group psychology (pp. 555-579). Chichester: Wiley.

Wilson, J. (2016). Making loan decisions in banks: straight from the gut? Journal of Business Ethics, 13(7), 53-63.

World Bank (2020). World Bank World Development Indicators. Retrieved from http://data.worldbank.org/. Accessed 10 July 2020.

Yoder, J. (2001). Making leadership work more effectively for women. Journal of Social Issues, 57(4), 815-828.

Yousafzai, S. Y., Saeed, S., \& Muffatto, M. (2015). Institutional theory and contextual embeddedness of women's entrepreneurial leadership: evidence from 92 countries. Journal of Small Business Management, 53(3), 587-604. https://doi. org/10.1111/jsbm.12179.

Publisher's note Springer Nature remains neutral with regard to jurisdictional claims in published maps and institutional affiliations. 